\title{
接近流が常流の場合の横流出を伴う流量式 DISCHARGE FORMULA OF SIDE-WEIR IN SUBCRITICAL OPEN-CHANNEL FLOWS
}

\author{
鬼束幸樹 1 ・秋山壽一郎 $2 \cdot$ 常松智博 3 ・武田雅俊 4 \\ Kouki ONITSUKA, Juichiro AKIYAMA, Tomohiro TSUNEMATSU and Masatoshi TAKEDA \\ 1正会員 博 (工） 九州工業大学助教授 工学部建設社会工学科（广804-8550 北九州市戸畑区仙水町1-1） \\ 2正会員 Ph. D. 九州工業大学教授 工学部建設社会工学科 \\ 3学生員 九州工業大学大学院 工学研究科博士前期課程 \\ 4学生員 九州工業大学 工学部建設社会工学科
}

\begin{abstract}
Several discharge formulae, which can predict the discharge per unit width in open-channel flows with a sideweir, have been suggested as yet. The discharge coefficients in such formulae were obtained empirically. In this study, the velocity measurements in subcritical open-channel flows were conducted with an electromagnetic current meter and also the flow depth measurements were conducted with a point gauge, with changing the inlet Froude number and the ratio between the inlet flow depth and the length of the side-weir. It was found that the direction of the velocity on the side-weir is almost constant in the vertical direction, but those changes in the streamwise direction. The relationship between the direction of such velocity and the inlet Froude number and the ratio between inlet flow depth and the length of the side-weir was made clear. As a result, a new discharge formula of side-weir in subcritical open-channel flows with zero height was suggested.
\end{abstract}

Key Words : discharge formula, side-weir, subcritical open-channel flows, theoretical formula

\section{1.はじめに}

近年都市部では，急激な都市化に伴い流出係数が増加 している. その結果，提内地で床上・床下浸水が頻発し， 流域住民は大きな経済的ダメージを受けている.これら の問題を解消する方法には, 透水性舗装の拡充, 緑地保 全および河道断面の確保などが挙げられる.こうした総 合治水対策は着々と進行しつつあるが，それらの完成に はまだ多くの時間が必要とされる. 一方で, 出水の被害 を緊急避難的に回避する方法として, 横越流を利用した 洪水調節池が挙げられる. これは, 河川の水位が上昇し たときに, 流量の一部が河道の側岸に設置された横越流 堰を越流し，洪水調節池に一時貯留することで本川の流 量を低減させ, 下流側流域の安全を確保するものである. 実際に，荒川水系神田川の一支流である妙正寺川に妙正 寺川調節池群, 目黒川に目黒川船入場調節池, 北九州市 戸畑区の天籁寺川に天籟寺川地下調節池などが建設され ている.

横越流堰を越流する流量式を初めて水理学的見地から 求めたのはDe Marchi ${ }^{1}$ である. 彼は摩擦抵抗を無視し, 比エネルギーが一定であるとの仮定から流量式を導き出
した. ただし, 流量式に含まれる流量係数の定量評価を 行わなかったため, De Marchi ${ }^{1}$ 式が実際に利用されるこ とはほとんどなかった. その後, 流量係数を実験的に求 める研究が開始された. Ackers ${ }^{2}$ は水理条件にかかわら ず流量係数が 0.625 定数であると考えた. 中川・宇民3) は, 流量係数は普遍ではなく堰高およびフルード数の影 響を受けると考え，これらを系統的に変化させた実験を 行い, 常流の場合は流量係数がフルード数の減少関数で あることを図示した. Subramanya \& Awasthy ${ }^{4}$ は次元解 析を行った結果, 流量係数を決定するパラメータは, フ ルード数, 相対堰高（=堰高と流入水深との比）, 相対 堰長(=堰長と主水路幅との比)および相対水深(=流入水深 と堰長との比)の 4 つであることを解明した. 彼らは 4 つのパラメータの内, 前者の 2 つが支配的であると推定 し, それらを変化させた流れで流量係数を求めた. その 結果, 相対堰高, 相対堰長および相対水深の影響は微小 であり, 流量係数はフルード数の一価関数であるとの結 論に達し, 流量係数とフルード数の関係を定式化した.

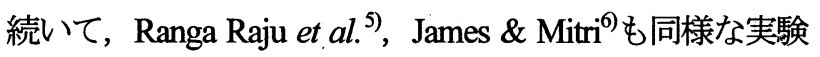
を行い, Subramanya \& Awasthy)の式を若干補正した実 験公式を提案した. このように, Subramanya \& Awasthy 
4)の研究以降, 流量係数はフルード数の一価関数として 扱われてきた. しかし，室田らクはフルード数だけでな く相対堰長も流量係数に影響を与えると指摘し, Singh et al. ${ }^{8}{ }^{8}$ およびHager" ${ }^{9}$ は相対堰高も流量係数に影響を与え ると指摘し, また, Borghei et al. ${ }^{10}$ は相対堰長も流量係 数に影響を与えると指摘した. 以上のように，流量係数 を決定するパラメータの選択は研究者によって異なって いる. この背景として, 流量式を求める上で接近流速お よび相対堰高の影響を無視していること, 複数のパラ メータの内の一つのパラメータだけを系統的に変化させ, その他のパラメータを固定することが実験的に困難なこ とが挙げられる.そこで, パラメータを減じるために, 相対堰高をゼロとすれば，その他のパラメータを系統的 に変化させる実験が可能となり，流量係数に及ぼす各パ ラメータの寄与率が解明される. 仮に寄与率が小さなパ ラメータが抽出できれば，相対堰高が有限な場合の実験 でもそのパラメータを無視できる可能性があり，系統的 な実験につながる，その結果，あらゆる条件に適用でき る流量式を提案することが可能となる.

本研究では，こうしたプロセスの第 1 段階として，相 対堰高がゼロの横越流堰において，フルード数および相 対水深を系統的に変化させ，その影響を検討する.

\section{2. 理論的考察}

図-1に横越流堰の概要を示す.水路床に沿って流下方 向に $x$ 軸， $x$ 軸に直角上向きに $y$ 軸，横断方向に $z$ 軸を とる. $x$ および $z$ 方向の時間平均流速を $U, W$ とし, $x-z$ 平面上の合成流速を $V$ する. $L$ は堰長, $B$ は主水 路幅， $S$ は堤高， $h$ は堤上からの水位， $\varphi$ は越流する流 れの方向と $x$ 軸との交差角度である．横越流堰区間への 流入断面を 1 , 流出断面を 2 , 堰上の断面を $w$ として変 数の添字とした. 前提条件として全区間で常流とし, 摩 擦勾配を無視する. 主水路の流量を $Q$ とすると堰上の 単位幅当たりの越流量 $q_{*}$ は次式で与えられる.

$$
q_{*}=-d Q / d x=h_{w} V_{w} \sin \varphi
$$

De Marchi ${ }^{1}$ は流入断面 1 から堰上断面 $w$ 一と流出する流 れにおいて，比エネルギーが一定と仮定した.

$$
\frac{V_{1}^{2}}{2 g}+h_{1}=\frac{V_{w}^{2}}{2 g}+h_{w}+S
$$

ここに, $g$ は重力加速度である. 横越流堰に接近する流 れが常流の場合, 堰上において限界流となる. よって, $V_{w}=V_{c}$ および $h_{w}=h_{c}$ となる. 添字 $c$ は限界流を示して いる. フルード数の定義 $F r \equiv V / \sqrt{g h}$ を式(2)に代入し, 堰上で限界流になることを利用すると次式が得られる。

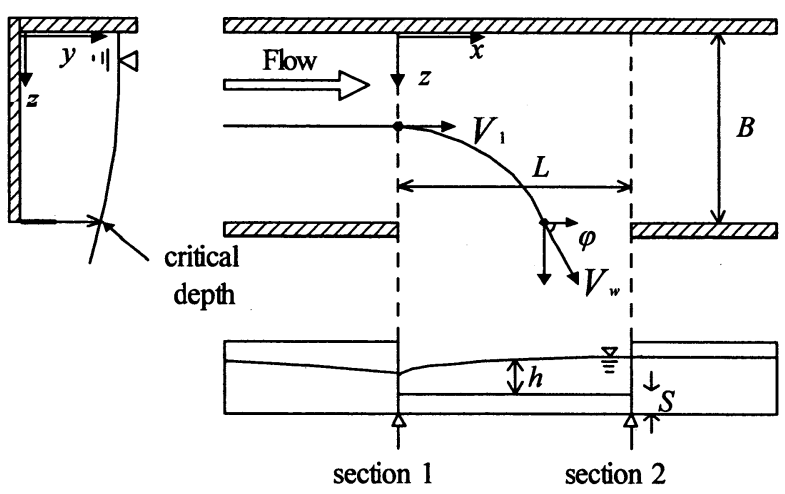

図-1 横越流堰の概要

$$
\begin{aligned}
& V_{w}=V_{c}=\sqrt{\frac{2 g h_{1}}{3}\left(\frac{F r_{1}^{2}}{2}+1-\frac{S}{h_{1}}\right)} \\
& h_{w}=h_{c}=\frac{2 h_{1}}{3}\left(\frac{F r_{1}^{2}}{2}+1-\frac{S}{h_{1}}\right)
\end{aligned}
$$

一方，式(1)中の $\sin \varphi$ は理論的に求めることができない． Subramanya \& Awasthy ${ }^{4}$ は堰上流速の流下方向流速成分 は，堰区間にさしかかる直前の流速成分と等しいと仮定 して越流角度 $\varphi$ を求めた。

$$
V_{w} \cos \varphi=V_{1}
$$

さらに，彼らは接近流速および相対堰高の影響を無視し， 式(3)〜(5)を式(1)に代入して次式を得た.

$$
q_{*}=\frac{2}{3} C_{M} \sqrt{2 g} h^{3 / 2}
$$

$C_{M}$ は流量係数であり, Subramanya \& Awasthy ${ }^{4}$ は実験 結果に基づき次式を提案した.

$$
C_{M}=0.611 \sqrt{\left(1-3 F r_{1}^{3}\right) / F r_{1}{ }^{2}+2}
$$

彼らは，式(6)が堰高がゼロの場合だけでなく，有限の高 さを有する場合でも有効であると述べている.

Subramanya \& Awasthy) の流量式(6)は, 接近流速を無 視していることや相対堰高を無視して導出していること に問題がある．さらに，接近流が限界流の場合でも有限 の越流量があるにも関わらず，式(5)を用いると越流量が ゼロになる．そのため, 前者の問題を解決するために流 量倸数 $C_{M}$ が導入されている. Subramanya \& Awasthy ${ }^{4)}$ の次元解析によると, 流量係数の支配パラメータは, フ ルード数 $F r_{1}$, 相対水深 $h_{1} / L$, 相対堰長 $L / B$ および相 対愝高 $S / h_{1}$ の 4 つされている. しかし，これらの八゚ ラメータの内，一つだけを変化させてその他のパラメー 夕を固定することは実験上困難である. そのため, 既往 の研究における流量倸数には実際は上述の 4 つのパラ メータの影響があるものの，定式化に当たっては少数の パラメータだけで記述しているために，各研究者の提案 式にばらつきが発生していると考えられる. 


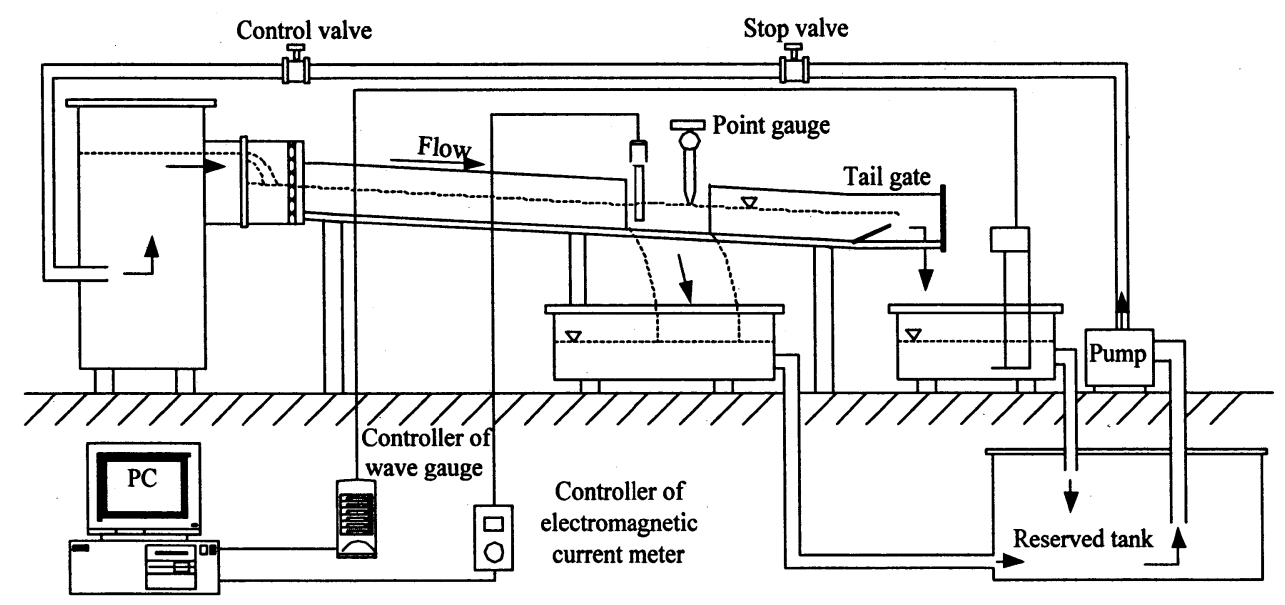

図-2 実験水路および実験装置

表-1 実験条件 $(L / B=0.25)$

\begin{tabular}{|c|c|c|c|}
\hline$h_{r_{1}} / L$ & 0.4 & 0.6 & 0.8 \\
\hline 0.2 & $\bigcirc$ & $\bigcirc$ & $\bigcirc$ \\
\hline 0.4 & $\bigcirc$ & $\bigcirc$ & $\bigcirc$ \\
\hline 0.6 & $\bigcirc$ & $\bigcirc$ & $\bigcirc$ \\
\hline 0.8 & $\bigcirc$ & $\bigcirc$ & $\times$ \\
\hline
\end{tabular}

\section{3. 実験装置および実験条件}

実験に使用した水路は図-2に示すような，全長 $5.0 \mathrm{~m}$, 高さ $30 \mathrm{~cm}$ ，主水路幅 $40 \mathrm{~cm}$ のアクリル製水路で，水路床 勾配 $\sin \theta$ は $1 / 2000$ に固定されている. 越流区間の長さ $L$ は $10 \mathrm{~cm} て ゙$, 水路上端 $3.0 \mathrm{~m}$ からはじまっている.

実験条件は表-1に示すように，相対堰長 $L / B$ を 0.25 に固定した状態でフルード数 $F r_{1}$ を0.2から 0.8 まで 0.2 刻 みで変化させ, 相対水深 $h_{1} / L$ を0.4から 0.8 ま 0.2 刻み で変化させた．本来ならば相対堰長 $L / B$ も系統的に変 化させるべきであるが，それには膨大な実験を行わなけ ればならない．そのため，相対堰長 $L / B$ を0.25に限定 した状態の実験とした．表中の○印は計測が可能である ことを表している．×印は装置の制約のため，実験がで きなかったケースである。

測定項目は，流量計測，水面形計測および流速計測で ある. 水路流入部付近に設けられた四角堰において流入 流量 $Q_{1}$ が計測される. 主水路下流側の量水槽には容量 式波高計が設置されており, 帰還パイプを一時塞いで水 面上昇速度を計測することで下流側流量 $Q_{2}$ が計測され る. 越流量 $Q_{w}$ は流入流量 $Q_{1}$ から下流側流量 $Q_{2}$ を减ず ることで求められる. なお, 四角堰による流量計測の誤 差は3\%程度と確認されている.

水面形計測には，ディジタル式ポイントゲージを用い た. 堰区間において流下方向に4点, 横断方向に4点とし たが，堰上では流下方向に7点とした。

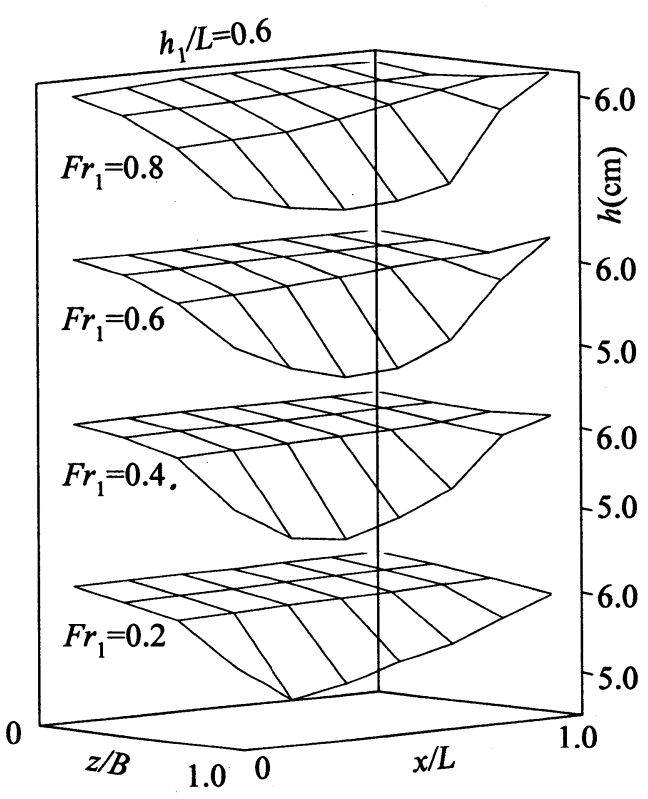

図-3(a) 水面形 $\left(h_{1} / L=0.6\right)$

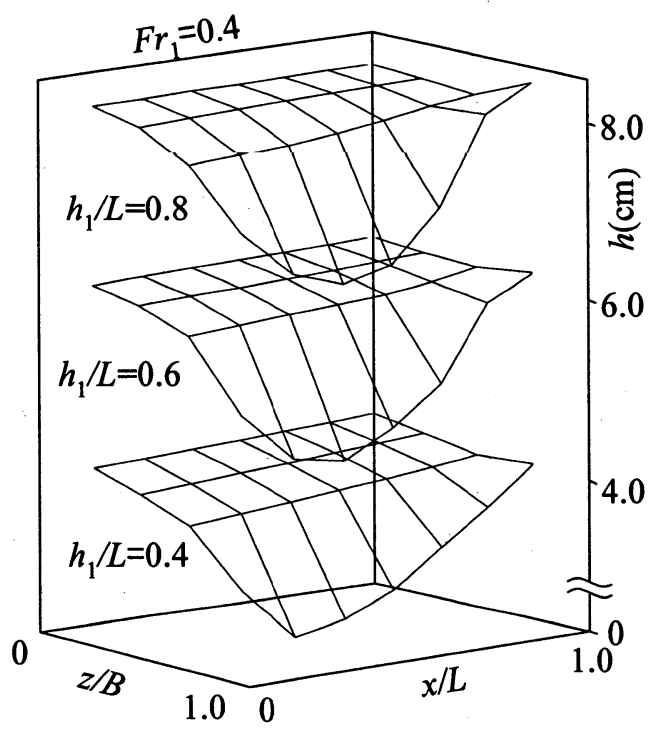

図-3(b) 水面形 $\left(F r_{1}=0.4\right)$ 
電磁流速計を用いて時間平均の流下方向流速 $U$ およ び横断方向流速 $W$ を検出した. 水面形計測と同様な水 平面の格子点において，水深方向に3点の測定点を設け， サンプリング間隔 $0.05 \mathrm{~s}$ ，サンプリング時間 $51.2 \mathrm{~s}$ とした.

\section{4. 実験結果および考察}

（1） 水面形に及ほすすフルード数および相対水深の影響

図-3(a)および(b) に相対水深 $h_{1} / L$ を0.6に固定してフ ルード数 $F r_{1}$ を系統的に変化させた場合およびフルード 数 $F r_{1}$ を0.4に固定して相対水深 $h_{1} / L$ を変化させた場合 の水面形を示す. 図-3(a) ではフルード数 $F r_{1}$ の増加に 伴い堰終端付近の水位が上昇しており，図-3(b)でも相 対水深 $h_{1} / L$ の増加に伴い堰終端付近の水位が上昇して いる.これは，両パラメータが越流量に影響を及ぼすこ とを示唆するものであり，流量式を構成する上でフルー ド数 $F r_{1}$ だけでなく相対水深 $h_{1} / L$ もパラメータとして 用いる必要があることを示している.

\section{（2）流速ベクトルの鉛直方向変化}

図-4にフルード数 $F r_{1}$ が 0.4 で相対水深 $h_{1} / L$ が 0.6 の ケースにおける水平面内の流速べクトルの鉛直方向変化 を示す.いずれの断面においても堰から離れた左岸付近 では堰の影響をほとんど受けずに流れが流下している。 堰上 $(z / B=1.0)$ の流速に着目すると, 流下に伴い越流角 度 $\varphi$ が増加している様子が観察される. 一方, 堰上の越 流角度 $\varphi$ の鉛直方向変化は, 後に示すフルード数 $F r_{1}$ お よび相対水深 $h_{1} / L$ の変化に伴う越流角度の変化と比較 すると微少である.

\section{（3）堰上での越流角度の変化}

図-5 (a) および(b)に相対水深 $h_{1} / L$ を0.6に固定してフ ルード数 $F r_{1}$ を系統的に変化させた場合およびフルード 数 $F r_{1}$ を0.4に固定して相対水深 $h_{1} / L$ を変化させた場合 の堰上ベクトルを示す．図-5(a)を見ると，フルード数 $F r_{1}$ の増加に伴い堰上ベクトルの長さが短くなっている 様子が観察される.これは，フルード数 $F r_{1}$ が増加する と接近流速水頭が増加するために生じたものであり，式 (3)より理論的に証明することができる. 一方，図-5(b) を見ると, 越流角度 $\varphi$ に及ぼす相対水深 $h_{1} / L$ の影響は, フルード数 $F r_{1}$ ほど顕著ではないが，相対水深 $h_{1} / L$ の 増加に伴い越流角度 $\varphi$ が減少する様子が観察される。 ま た, 後述するが, 両図より越流角度 $\varphi$ の変化率は堰始端 $(x / L=0)$ 直後では流下方向に急激に変化しているのに対 し, 堰終端 $(x / L=1)$ 直前では変化が緩慢になっているこ とも観察される.
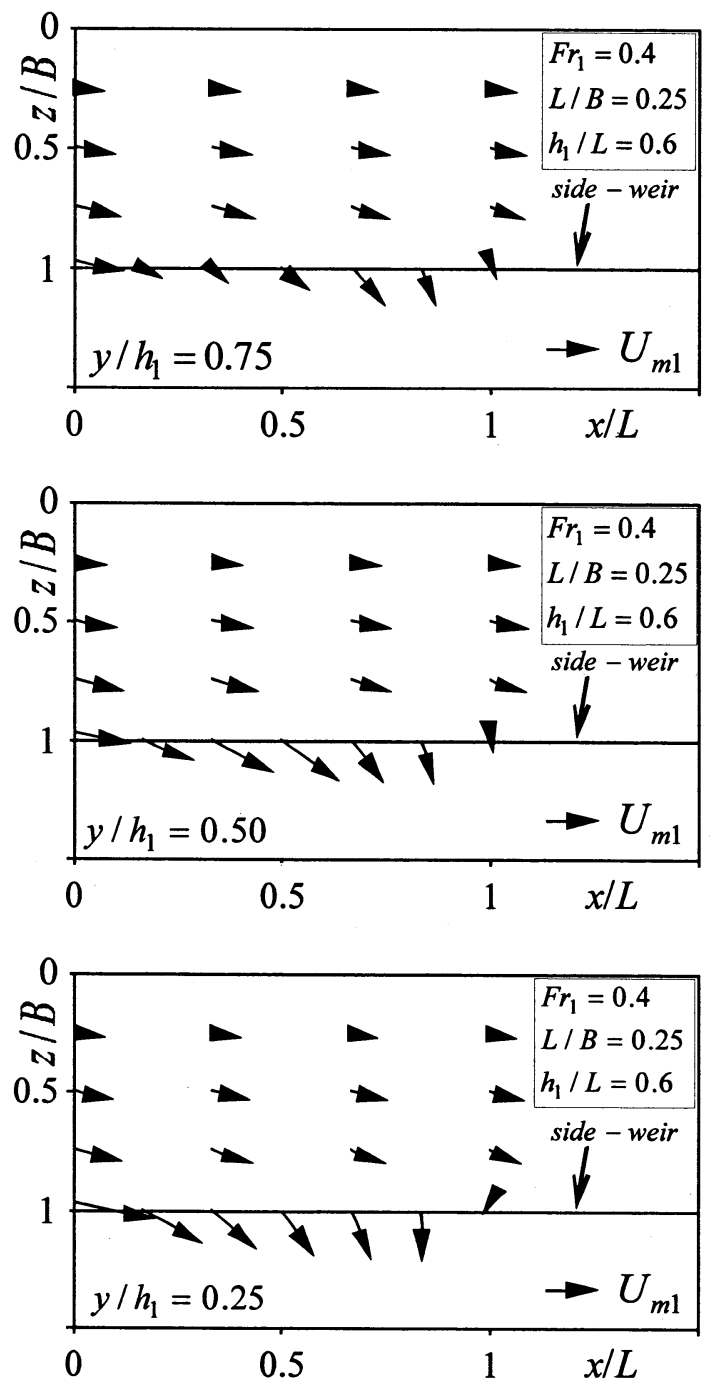

図-4 流速ベクトルの鉛直方向変化

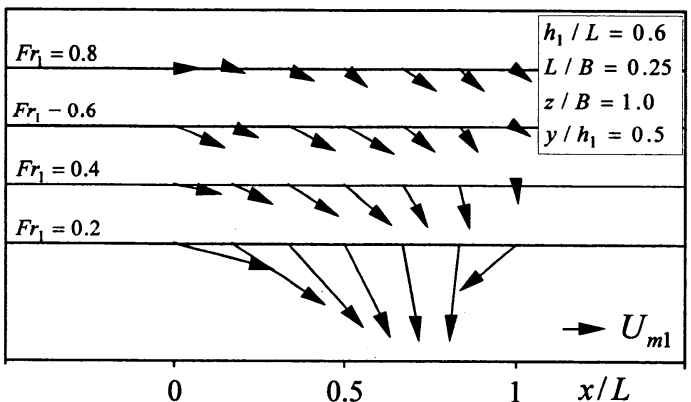

図-5(a) 堰上での越流角度の変化 $\left(h_{1} / L=0.6\right)$

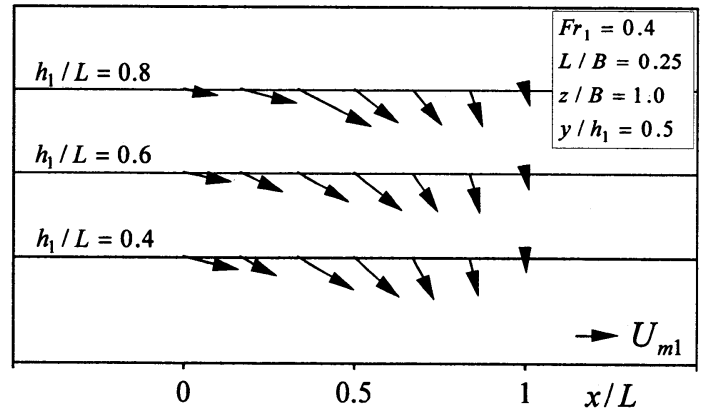

図-5 (b) 堰上での越流角度の変化 $\left(F r_{1}=0.4\right)$ 

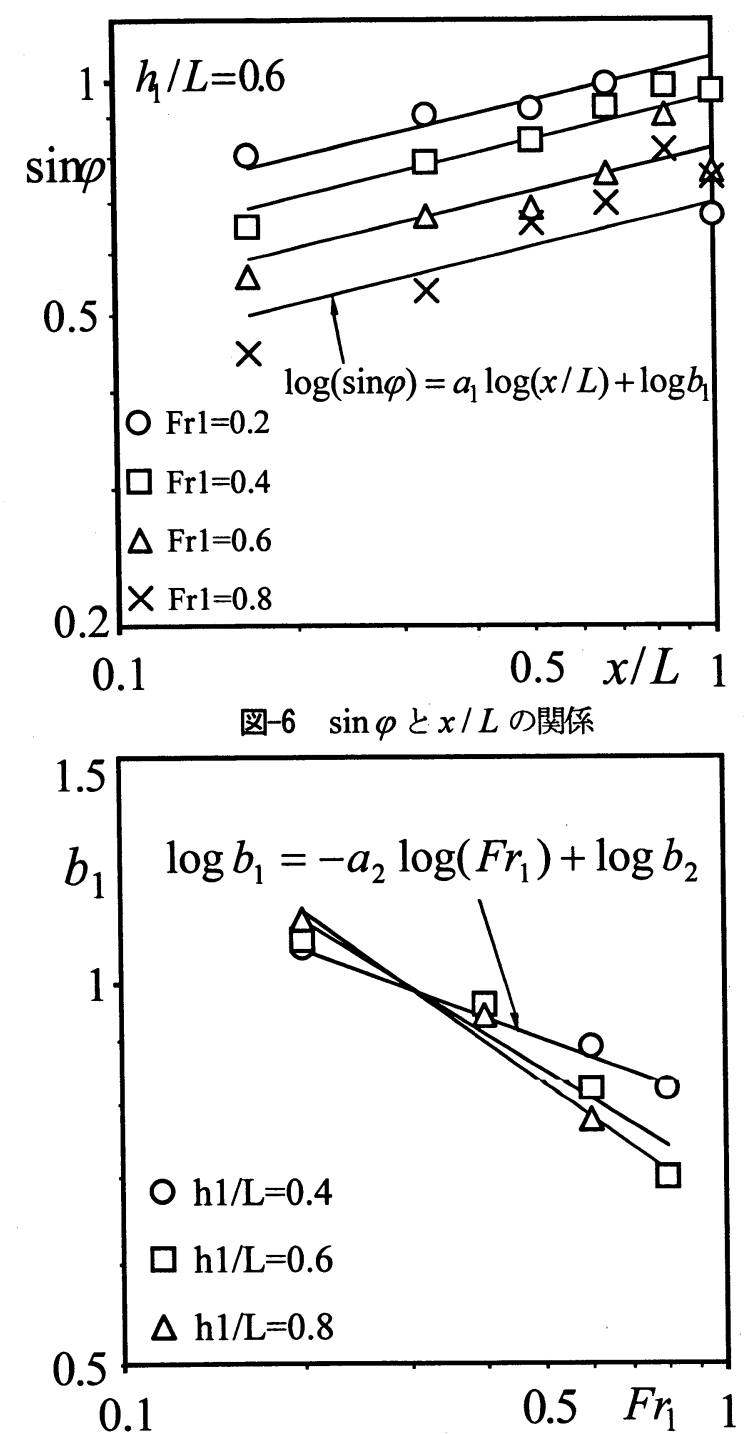

図-7 切片 $b_{1}$ と $F r_{1}$ の関係

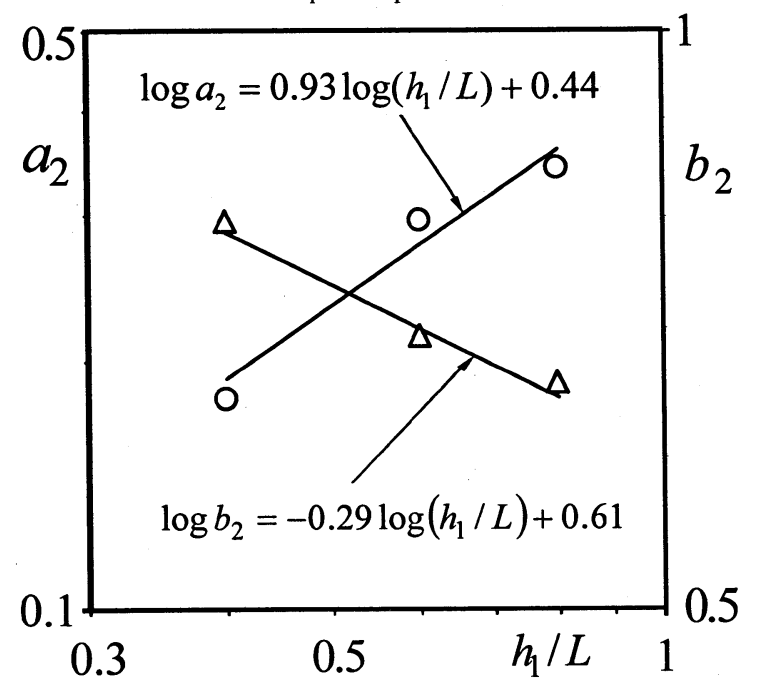

図-8 傾き $a_{2}$ および切片 $b_{2}$ と $h_{1} / L$ の関係

\section{（4）堰上での越流角度の定式化}

図-5より越流角度 $\varphi$ の変化率が流下に伴って減少して いることが判明した．そこで，図-6に各フルード数 $F r_{1}$ ごとの越流角度の正弦成分 $\sin \varphi$ の流下方向変化を両対

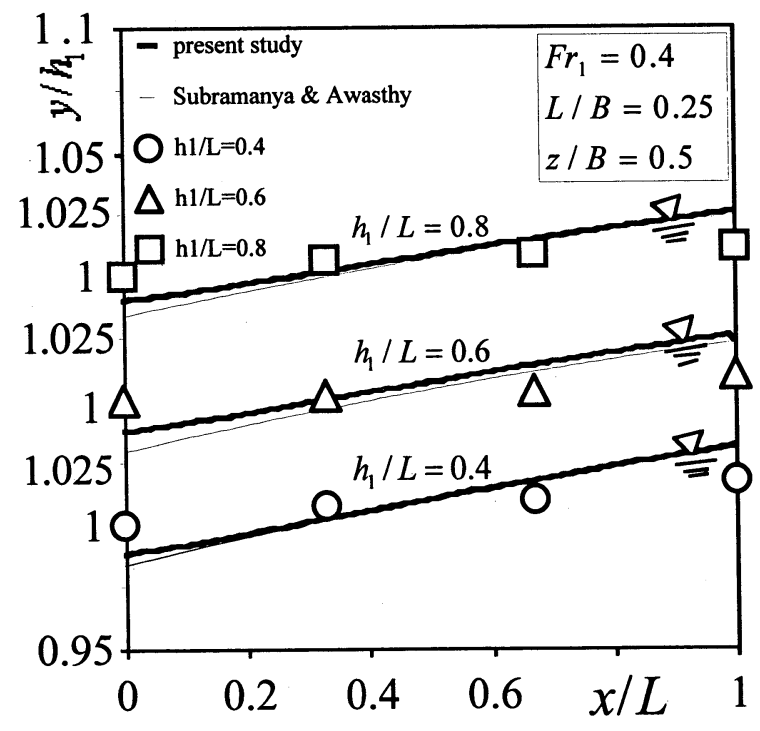

図-9 水面形の予測值 $\left(F r_{1}=0.4\right)$

数表示する. なお, $\sin \varphi$ は $y / h_{1}=0.25,0.50,0.75$ の断 面における越流角度 $\varphi$ を平均して求めた. いずれのフ ルード数 $F r_{1}$ においても $\sin \varphi$ は流下方向に増加してい る. 多少のばらつきがあるものの，両者の関係は線形的 なので，次式で両者の関係を近似的に表した。 $\log (\sin \varphi)=0.19 \log (x / L)+\log \left(b_{1}\right)$

傾き $a_{1}$ に着目すると, フルード数 $F r_{1}$ が 0.8 の時はそれ以 下のフルード数の時よりも大きな傾向があるものの, 系 統的な変化が見られないことから，ここでは傾き $a_{1}$ を 一定值とした. その結果， $a_{1}$ は 0.19 と算出された. 一 方, 切片 $b_{1}$ はフルード数 $F r_{1}$ および相対水深 $h_{1} / L$ に依 存すると考えられる.

図-7に相対水深 $h_{1} / L$ ごとのフルード数 $F r_{1}$ と切片 $b_{1}$ との関係を両対数表示する. いずれの相対水深 $h_{1} / L$ に おいてもフルード数 $F r_{1}$ の増加に伴い切片 $b_{1}$ が減少して いる. また，両者の関係が線形的であると判断される. そこで, 両者の関係を次式で近似し，傾き $a_{2}$ および切 片 $b_{2}$ を算出した.

$$
\log \left(b_{1}\right)=-a_{2} \log \left(F r_{1}\right)+\log \left(b_{2}\right)
$$

傾き $a_{2}$ および切片 $b_{2}$ は相対水深 $h_{1} / L$ の関数となる.

図-8に相対水深 $h_{1} / L$ と傾き $a_{2}$ と切片 $b_{2}$ の関係を両 対数表示する. 同様に次式が求められる.

$$
\begin{aligned}
& \log \left(a_{2}\right)=0.93 \log \left(h_{1} / L\right)+\log 0.44 \\
& \log \left(b_{2}\right)=-0.29 \log \left(h_{1} / L\right)+\log 0.61
\end{aligned}
$$

式(8)〜式(11)から $\sin \varphi$ を示す次式が求められる

$$
\sin \varphi=(x / L)^{0.19} \times F r_{1}^{-0.44\left(h_{1} / L\right)^{0.93}} \times 0.61\left(h_{1} / L\right)^{-0.29}
$$

\section{（5）水面形および越流量の予測}

本研究で提案した式(12)と式(1)，(3)，(4)および次式に 水路下流の実測水深を境界条件として与えると, 水面形 および越流量の予測值が求められる. 


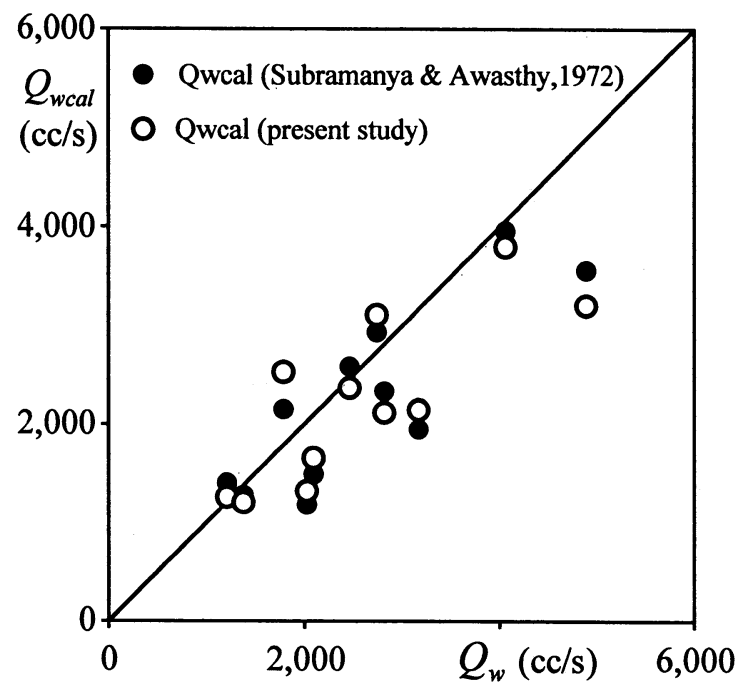

図-10 実測越流量 $Q_{w}$ と予測越流量 $Q_{w c a l}$ の関係

$$
\frac{d h}{d x}=\frac{\sin \theta+Q q^{+} /\left(g A^{2}\right)}{\cos \theta-Q^{2} B /\left(g A^{3}\right)}
$$

ここに，A は断面積である. 同様に, 式(6), (7)および 式(13)からSubramanya \& Awasthy ${ }^{4}$ の予測值が求められる. 図-9にフルード数 $F r_{1}$ を 0.4 に固定して相対水深 $h_{1} / L$ を 変化させた場合の水面形を示す.プロットが実験值で太 線が式(12)を用いた予測值で, 細線がSubramanya \& Awasthy ${ }^{4}$ 式の予測值である．堰中央から終端にかけては 両計算結果に大きな差違は見られないが，堰始端付近で は本計算結果の方が若干良好な予測となった。

図-10に予測越流量 $Q_{w c a l}$ と実測越流量 $Q_{w}$ の関係を示 す. 白丸は式(12)を用いた予測值で，黒丸はSubramanya \& Awasthy ${ }^{4}$ 式の予測值である. 式(12)を用いた予測越流 量は必ずしもSubramanya \& Awasthy)の予測越流量より も誤差が小さいとは限らず，精度は同程度である．ただ し，式(12)は相対堰長が考慮されている点が優れている。

\section{5. おわりに}

横越流堰における越流量はフルード数 $F r_{1}$, 相対水深 $h_{1} / L$, 相対堰長 $L / B$ および相対堰高 $S / h_{1}$ の 4 つのパ ラメータの影響を受ける. しかし，既往の研究ではこれ らのパラメータを独立に変化させて実験していないため, 各研究者が提案した流量係数に差異が生じている. 本研 究では, 相対堰高がゼロの場合で接近流が常流の横越流 堰において, 相対堰長 $L / B$ を固定した状態で, フルー ド数 $F r_{1}$ および相対水深 $h_{1} / L$ を系統的に変化させて流 量, 水面形および流速測定を行った. その結果得られた 知見を以下に示す。

（1）横越流堰による流速場への影響は堰周辺のみで，対 岸にはほとんど影響を与えない.
(2) 堤上の流向は鉛直方向にはほとんど変化がなく，流 下方向の変化量が支配的であり, 鉛直方向には 2 次元的 とみなせる.

(3) 相対堰高 $S / h_{1}$ がゼロで相対堰長 $L / B$ が0.25におけ る新たな流量式を式(1)，(3)，(4)および(12)のように提案 した. 式(12)を用いた越流量の予測精度はSubramanya \& Awasthy ${ }^{4}$ 式と同程度であるが, 水面形の予測精度は彼ら のものよりも良好であった.

(4) 本研究では, フルード数 $F r_{1}$ および相対水深 $h_{1} / L$ のみを変化させたが，相対堰長 $L / B$ の影響を考慮して おらず, また $h_{1} / L$ の範囲も狭いといえる. 今後, $L / B$ の影響も考慮すると共に, $h_{1} / L$ の範囲も実河川のもの に近づけて, 相対堰高 $S / h_{1}$ がぜロの場合の流量式を確 立したい. さらに, 相対堰高 $S / h_{1}$ が有限の場合の流量 式の確立に挑みたい.

謝辞 : 水路の組み立ておよひ配管工事に協力いただいた 九州工業大学学部生の松本和也氏に謝意を表す.

\section{参考文献}

1) De Marchi, G.: Essay on the performance of lateral weirs, $L$, Energia Elettrica, Milan, Italy, Vol.11, pp.849-860, 1934.

2) Ackers, P.: A theoretical considerations of side-weir a stream water outflows, Proc. of the Institute of Civil Engineers, London, Vol.6, 1957.

3) 中川博次, 宇民正 : 横越流分水工の機能設計に関する研究, 京大防災研年報，第9号，pp.539-550，1966.

4) Subramanya, A. and Awasthy, S.C.: Spatially varied flow over sideweirs, J. Hydraulics Division, ASCE, Vol.98, pp.1-10, 1972.

5) Ranga Raju, K.G., Prasad, B. and Gupta, S.K.: Side weir in rectangular channel, J. Hydraulics Division, ASCE, Vol.105, pp.547-554, 1979.

6) James, W. and Mitri H.: Modelling side-weir diversion structures for stormwater management, Canadian J. Civil Engineering, Vol.9, pp.197-205, 1982.

7) 室田明，福原輝幸，鉫田義浩 : 横越流堰の越流量の評価に関 する研究，土木学会論文集，第363号/II-4，pp.249-252，1985.

8) Singh, R. Manivannan, D. and Satyanarayana, T.: Discharge coefficient of rectangular side weirs, $J$. Irrigation and Drainage Engineering, Vol.120, pp.814-819, 1994.

9) Hager, W.H.: Lateral outflow over side weirs, J. Hydraulic Engineering, ASCE, Vol.113, pp.491-504, 1987.

10) Borghei, S.M., Jalili, M.R. and Ghodsian, M.: Discharge coefficient for sharp-crested side weir in subcritical flow, $J$. Hydraulic Engineering, ASCE, Vol.123, pp.1051-1056, 1999.

(2003. 9. 30受付) 